\title{
First record of larvae of Allograpta exotica Wiedemann (Diptera, Syrphidae) preying on Aphis gossypii Glover (Hemiptera, Aphididae) in watermelon in Brazil
}

\author{
Vinícius Soares Sturza ${ }^{1}$, Cecília Dorfey ${ }^{1}$, Sônia Poncio², Sônia Thereza Bastos Dequech ${ }^{3} \&$ Anderson Bolzan ${ }^{3}$
}

${ }^{1}$ Programa de Pós-graduação em Agronomia, Universidade Federal de Santa Maria, Avenida Roraima, Bairro Camobi, 1000, 97105-900 Santa
Maria-RS, Brazil. Fellowship CAPES. vsturza27@yahoo.com.br; cecilia.dorfey@gmail.com
2Programa de Pós-graduação em Agrobiologia, Universidade Federal de Santa Maria, Avenida Roraima, Bairro Camobi, 1000, 97105-900 Santa
Maria-RS, Brazil. Fellowship CAPES. soniaponcio@yahoo.com.br
32Departamento de Defesa Fitossanitária, Centro de Ciências Rurais, Universidade Federal de Santa Maria, Avenida Roraima, Bairro Camobi, 1000,
97105-900 Santa Maria-RS, Brazil. soniatbd@gmail.com; ander_bolzan@hotmail.com

\begin{abstract}
First record of larvae of Allograpta exotica Wiedemann (Diptera, Syrphidae) preying on Aphis gossypii Glover (Hemiptera, Aphididae) in watermelon in Brazil. Brazil is one of the largest world producers of watermelon (Citrullus lanatus Thumb. Mansf.) and Aphis gossypii Glover, 1877 (Hemiptera, Aphididae) is among the most important pest on this crop. Larvae of Allograpta exotica Wiedemann, 1830 (Diptera, Syrphidae) were found preying on A. gossypii in watermelon crop, in Santa Maria, Rio Grande do Sul State, what represents the first report of this tritrophic association in Brazil.
\end{abstract}

KEYWORDS. Aphids; cucurbit; predator; tritrophic association.

RESUMO. Primeiro relato de larvas de Allograpta exotica Wiedemann (Diptera, Syrphidae) predando Aphis gossypii glover (Hemiptera, Aphididae) em melancia no Brasil. O Brasil é um dos maiores países produtores de melancia e Aphis gossypii Glover, 1877 (Hemiptera, Aphididae) está entre as pragas mais importantes da cultura. Larvas de Allograpta exotica Wiedemann, 1830 (Diptera, Syrphidae) foram registradas predando A. gossypii em cultivo de melancia em Santa Maria, Rio Grande do Sul, o que representa o primeiro relato desta associação tritrófica no Brasil.

PALAVRAS-CHAVE. Afídeos; associação tritrófica; cucurbitáceas; predador.

Watermelon (Citrullus lanatus Thumb. Mansf.) is one of the most important cucurbit crops in the world, and Brazil is the fourth largest producer, with a total area of 90.000 ha and average annual national production of about 2 million $t$ (FAO 2008). In the state of Rio Grande do Sul (RS), the largest national producer, cultivation is seasonal (spring-summer) and represents an alternative source of income, especially for small producers because of its high productivity, compared to other vegetables, which is $25.6 \mathrm{t}^{\text {. ha-1 }}$ (IBGE 2008).

Aphids are among the most common pests in cultivated cucurbits (Bueno 2005; Andrade Júnior et al. 2007; Baldin et al. 2009). Aphis gossypii Glover, 1877 (Hemiptera, Aphididae) is widely distributed in regions of agricultural production, being of economic importance in watermelon as well as in other annual, perennial, and vegetable crops (Santos et al. 2004; Bueno 2005; Piero et al. 2006). This aphid species presents a high biotic potential, causing direct and indirect damages as a vector of Papaya ringspot virus - Type W (WPRSV-W), Zucchini Yellow Mosaic Virus (ZYMV) and Cucumber Mosaic Virus (CMV), which attack cucurbits
(Bueno 2005; Andrade Júnior et al. 2007; Pinto et al. 2008; Silva et al. 2008).

Although many studies have reported parasitoids associated with A. gossypii (Rodrigues \& Bueno 2001; Torres et al. 2007; Silva et al. 2008), there is scarce information about other groups of natural enemies associated with this aphid, such as predators, especially in field conditions. Therefore, this justifies both the searching and recording of new species to be considered and possibly included in pest management strategies.

The objective of this paper is to report the association of Allograpta exotica Wiedemann, 1830 (Diptera, Syrphidae) larvae preying on $A$. gossypii in watermelon in the State of Rio Grande do Sul, Brazil.

A watermelon crop was cultivated at an experimental area of the Departamento de Fitotecnia of the Universidade Federal de Santa Maria, Santa Maria, RS, coordinates $29^{\circ} 43^{\prime} \mathrm{S}$, $53^{\circ} 43^{\prime} \mathrm{W}, 95 \mathrm{~m}$ asl and Cfa climatic type, according to the Köppen classification (Moreno 1961). This crop was conducted during the 2009/2010 growing season (spring-summer). Trans- 
plantation was made on November $12^{\text {th }}$ and the genotype used was Crimson Sweet because it is the most planted genotype in Brazil (Ferreira et al. 2003) and because it is well adapted to the region. The total area was $75 \mathrm{~m}^{2}$, planted with 60 plants spaced at $1.25 \times 1.00 \mathrm{~m}$. Fertilization was made according to soil chemical analysis. The area was kept free of weeds by hoeing and no chemical control for pests or diseases was applied. Visual observations of the occurrence of pests were made three times a week (Mondays, Wednesdays and Fridays) examining all plants. As soon as of the first specimens of aphids and Syrphidae larvae were detected simultaneously, 12 plants were chosen randomly every day and the insects were collected, until their occurrence stopped. Six surveys were made and leaves with Syrphidae and aphids were collected, kept in $250 \mathrm{~mL}$ plastic cups and transported to the laboratory where the larvae were counted, separated by date of survey and kept under controlled temperature and humidity $\left(25 \pm 2{ }^{\circ} \mathrm{C}\right.$ and 60 $\pm 10 \%)$. Aphids were offered to larvae in the laboratory until the syrphid pupated. Thirty five syrphid larvae were found and two of them (collected on January $14^{\text {th }}$ ) have reached adult stage. These adult syrphids as well the aphids were sent to specialist for proper identification.

Only a single species of both Aphididae and Syrphidae were identified, Aphis gossypii and Allograpta exotica, respectively. Voucher specimens of $A$. exotica were deposited at the Entomological Collection of the Departamento de Zoologia, at the Universidade Federal do Paraná. Although all syrphid specimens reached the pupal stage, most of the pupae did not reach adulthood probably because of inadequate moisture conditions in the rearing containers.

Larvae of Syrphidae are important predators, mainly of hemipteran pests (Mengual et al. 2009). In Brazil, other Allograpta species occur as natural biological control agents of Gyropsylla spegazziniana Lizer \& Trelles, 1919 (Hemiptera, Psyllidae), preying on its nymphs inside vials in native and managed cultivation areas of yerba mate (Ilex paraguariensis A. St. - Hil.) (Borges \& Lazzari 2008) and are also predators of Bemisia tabaci Gennadius, 1889 and Trialeurodes vaporariorum Westwood, 1856 (Hemiptera, Aleyrodidae) in crops of tobacco, cotton, tomato, cabbage, soybean, beans, melon and eggplant (Oliveira et al. 2003).

Some species of Allograpta have also been recorded in association with several species of aphids, having an important role in natural biological control of this group. They are found feeding primarily on aphids that infest citrus, subtropical fruit trees, corn, alfalfa, cotton, grapes, lettuce, ornamentals, and also many wild plants (Ghahari et al. 2008). Resende et al. (2006) reported that $A$. exotica is the most abundant species of Syrphidae collected from leaves of cabbage feeding on aphids.

The predation of $A$. gossypii by $A$. exotica larvae is unprecedented for watermelon in Brazil, showing that there is still lack of information about natural predators, in this crop, especially in RS State. Conservation practices to maintain and increase populations of $A$. exotica should be investigated. Planting and maintenance of border areas using plants that provide resources (pollen and nectar) might have great beneficial impact for augmenting populations of this predator. Such areas also provide moderate microclimate that serves as shelter and protection when environmental conditions become adverse, mainly in periods of excessive heat or rain (Venzon et al. 2005).

Species of Syrphidae have been reared and released as control agents and have proved to be effective in suppressing A. gossypii populations in greenhouse (Pimentel et al. 2007). A. exotica among other species of Syrphidae represents an effective control agent to be studied and tested for integrated pest management in watermelon crops. Therefore, the occurrence of $A$. exotica we recorded should be considered as a good indicative of its potential to reduce $A$. gossypii populations in watermelon crops.

\section{ACKNOWLEDGMENTS}

To Dr. Carlos Roberto Sousa e Silva from Universidade Federal de São Carlos (UFSCar) for the identification of Aphis gossypii, and to M.Sc. Mírian Nunes Morales from Universidade Federal do Paraná (UFPR) for identification of Allograpta exotica. To Coordenação de Aperfeiçoamento de Pessoal de Nível Superior (CAPES) for granting fellowship to the authors Vinícius Soares Sturza, Cecília Dorfey and Sônia Poncio.

\section{REFERENCES}

Andrade Júnior, A. S.; B. H. N. Rodrigues; C. A. Sobrinho; E. A. Bastos; F. B. Melo; M. J. Cardoso; P. H. S. Silva \& R. L. R. Duarte. 2007. A Cultura da melancia. Brasília, Embrapa Informação Tecnológica, $2^{\mathrm{a}}$. ed., 85 p.

Baldin, E.; L. S. Marchi, \& E. C. Schlick. 2009. Resistance of squash cultivars to Aphis gossypii. Horticultura Brasileira 27: 366-370.

Borges, L. R. \& S. M. N. Lazzari. 2008. Flutuação populacional de Gyropsylla spegazziniana (Lizer Y Trelles) (Hemiptera: Psyllidae) em dois sistemas de cultivo de erva-mate, Ilex paraguariensis A. ST. Hill (Aquifoliaceae). Floresta 38: 325-330.

Bueno, V. H. P. 2005. Controle biológico de pulgões ou afídeos-praga em cultivo protegido. Informe Agropecuário 28: 9-17.

FAO. 2008. Faostat, Crops. Available from: http://faostat.fao.org/site/567/ DesktopDefault.aspx?PageID = 567\#ancor (accessed 29 May 2010).

Ferreira, M. A. J. F.; M. A. Queiróz; L. T. Braz \& R. Vencovsky. 2003. Correlações genotípicas, fenotípicas e de ambiente entre dez caracteres de melancia e suas implicações para o melhoramento genético. Horticultura Brasileira 21: 438-442.

Ghahari, H.; R. Hayat; M. Tabari \& H. Ostovan. 2008. Hover flies (Diptera: Syrphidae) from rice fields and round grasslands of Northern Iran. Munis Entomology and Zoology 3: 275-284.

IBGE. 2008. Produção Agrícola Municipal. Available from: http:// www.ibge.gov.br/home/estatistica/economia/pam/2008/tab2.pdf (acessed 9 June 2010).

Mengual, X.; C. Ruiz; S. Rojo; G. Stahls \& F. C. Thompson. 2009. A conspectus of the flower fly genus Allograpta (Diptera: Syrphidae) with description of a new subgenus and species. Zootaxa 2214: 1-28.

Moreno, J. A. 1961. Clima do Rio Grande do Sul. Porto Alegre, Secretaria da Agricultura do Estado do Rio Grande do Sul, 42 p.

Oliveira, M. R. V.; E. Amancio; R. A. Laumann \& L. O. Gomes. 2003. Natural enemies of Bemisia tabaci (Gennadius) B biotype and Trialeurodes vaporariorum (Westwood) (Hemiptera: Aleyrodidae) in Brasilia, Brazil. Neotropical Entomology 32: 151-154. 
Piero, R. M.; J. A. M. Rezende; V. A. Yuki; S. F. Pascholate \& M. A. Delfino. 2006. Transmissão do passion fruit woodiness vírus por Aphis gossypii (Glover) (Hemiptera: Aphididae) e colonização de maracujazeiro pelo vetor. Neotropical Entomology 35: 139-140.

Pimentel, D. 2007. Encyclopedia of Pest Management. New York, CRC Press, $784 \mathrm{p}$.

Pinto, Z. V.; J. A. M. Rezende; V. A. Yuki \& S. M. S. Piedade. 2008. Ability of Aphis gossypii and Myzus persicae to transmit Cucumber mosaic virus in single and mixed infection with two Potyviruses to zucchini squash. Summa Phytopathologica 34: 183-185.

Resende, A. L. S.; E. E. Silva; V. B. Silva; R. L. D. Ribeiro; J. G. M. Guerra \& E. L. Aguiar-Menezes. 2006. Primeiro registro de Lipaphis pseudobrassicae Davis (Hemiptera: Aphididae) e sua associação com insetos predadores, parasitóides e formigas em couve (Cruciferae) no Brasil. Neotropical Entomology 35: 551-555.

Rodrigues, S. M. M. \& V. H. P. Bueno. 2001. Parasitism rates of Lysiphlebus testaceipes (Cresson) (Hym.: Aphidiidae) on Schizaphis graminum (Rond.) and Aphis gossypii Glover (Hem.: Aphididae). Neotropical
Entomology 30: 625-629.

Santos, K. B.; P. M. J. Neves \& W. J. Santos. 2004. Resistência de cultivares de algodoeiro ao vírus do mosaico das nervuras transmitido pelo pulgão Aphis gossypii (Glover) (Hemiptera: Aphididae). Neotropical Entomology 33: 481-486.

Silva, R. J.; V. H. P. Bueno; D. B. Silva \& M. V. Sampaio. 2008. Tabela de vida de fertilidade de Lysiphlebus testaceipes (Cresson) (Hymenoptera, Braconidae, Aphidiinae) em Rhopalosiphum maidis (Fitch) e Aphis gossypii Glover (Hemiptera, Aphididae). Revista Brasileira de Entomologia 52: 124-130.

Torres, A. F.; V. H. P. Bueno; M. V. Sampaio \& B. F. Conti. 2007. Tabela de vida de fertilidade de Aphidius colemani Viereck (Hymenoptera: Braconidae, Aphidiinae) em Aphis gossypii Glover (Hemiptera: Aphididae). Neotropical Entomology 36: 532-536.

Venzon, M.; M. C. Rosado; D. E. Euzébio \& A. De Pallini. 2005. Controle biológico conservativo, p. 1-22. In: M. Venzon; T. J. Paula Júnior \& A. De Pallini. (Eds.). Controle alternativo de doenças e pragas. Viçosa, EPAMIG, 362 p.

Received 30/9/2010; accepted 29/4/201

Editor: Sonia Maria Noemberg Lázzari 